\title{
Basel III's Corporate Governance Impact: How Increased Banking Regulations Pose Challenges to Corporate Compliance While Simultaneously Furthering Stakeholder Objectives
}

\author{
Cory Howard \\ Wake Forest University, United States
}

\begin{abstract}
Basel III was primarily intended to provide additional regulations to prevent the collapse of financial institutions during times of liquidity crises. However, two primary reforms, namely the new capital adequacy framework and disclosure requirements, will not only prevent banks from failure during periods of financial distress, but also help promote corporate governance objectives. In the traditional model of corporate governance, shareholders will benefit from the stability of firms in which they have invested, as well as having access to accurate and complete financial statements. Additionally, non-shareholder stakeholders will benefit from increased systemic stability and avoiding the resulting problems that the 2007 financial collapse created, such as decreased access to consumer credit, stagnant wages, and skyrocketing unemployment. This article will attempt to outline the specific corporate governance benefits that Basel III will bring, focusing on how disclosure requirements and capital adequacy will help shareholders and stakeholders alike.
\end{abstract}

\section{Keywords}

Corporate Governance, Stakeholders, Basel III.

\section{Introduction}

The new Basel III banking regulations promulgated by the Basel Committee on Banking Supervision, while primarily intended to be a comprehensive set of international financial regulations intending to

Copyright (C) 2014 Victoria University. This document has been published as part of the Journal of Business Systems, Governance and Ethics in both online and print formats. Educational and non-profit institutions are granted a nonexclusive licence to utilise this document in whole or in part for personal or classroom use without fee, provided that correct attribution and citation are made and this copyright statement is reproduced. Any other usage is prohibited without the express permission of the publisher. address bank capital adequacy, have the potential to have significant effects on corporate governance. Undercapitalization in banks played a key role in the 2007 financial crisis, deepening it and allowing it to spread and touch almost every industry in almost every nation's economy. New capital standards approved by the Basel Committee and adopted by a number of states, including the United 
States ${ }^{1}$, have the potential to play a key role in corporate governance efforts by reducing risky, promanagement decision making patterns and increasing stability throughout the financial system. These benefits will positively impact not just shareholders, by promoting long-term and stable firm growth and management, but also have a beneficial on the livelihoods of non-shareholder stakeholders. Increasing the level and more importantly, the quality, of capital that banks and other financial institutions are required to hold will strengthen shareholder and stakeholder corporate governance efforts, at minimal cost to the firms involved.

Part II of this article will briefly discuss key reforms that Basel III has imposed, namely the rise in the level of capital, financial institutions must hold, as well as the strict requirements in the quality of the capital that can be counted for purposes of complying with the regulation. This discussion is by no means meant to be exhaustive or complete and is a basic look that is intended to give the reader a functional knowledge of the changes in order to better understand how this new set of banking standards will benefit corporate governance efforts. Part III of the article is intended to explicitly identify the connection between the imposition of new banking regulations and the benefits they impart in the realm of corporate governance by examining the practical effects on both shareholder and non-shareholder stakeholder objectives and platforms.

\section{KEY REFORMS PROPOSED BY BASEL III}

\section{A. Measurement of Quantity and Quality of Capital}

Basel III makes two primary changes to the existing banking regulation framework by (1) requiring an increase in the amount of common equity a bank must contain in relation to its riskweighted assets (RWAs) and (2) mandating an increase in Tier 1 capital ratios. ${ }^{2}$ Although, Basel III's capital ratios are based on Basel II's framework, they are significantly more onerous and, in fact, almost triple the size of bank's required capital reserve. ${ }^{3}$ While the increase from the current $4 \%$ required minimum to $8 \%$ in total capital held ${ }^{4}$ may seem like a drastic increase in capital reserve requirements, current banks have an average holding 8.79 per cent, well above the 7 per cent equity requirement of Basel III. ${ }^{5}$ Basel's risk-based capital ratio requires not just an aggregate increase in gross capital held, but increases the quality standards for capital that qualifies towards Tier 1 and Tier

\footnotetext{
${ }^{1}$ Tom Braithwaite, Banks Await Orders as Fed Acts on Basel III, FINANCIAL TIMES (July 2, 2013), http://www.ft.com/intl/cms/s/0/94abb696-e337-11e2-9bb2-00144feabdc0.html\#axzz2iboSFxb8 (noting that the Federal Reserve Board adopted the Basel III accord on July 2, 2013).

2 Johsua N. Rudin, Note, Basel III: The Banking Band-Aid?, 6 BrooK. J. CORP. FIN. \& COM. L. 621, 628 (2012).

${ }^{3}$ Candemir Baltali and Joseph Tanega, Basel III: Dehybridization of Capital, 8 N.Y.U. J. L. \& Bus. 1, 11 (2011).

${ }^{4}$ The $8 \%$ of total capital held requirement is further broken down as Common Equity Tier One capital (CET1) is required to be at least $4.5 \%$ of the risk weighted assets held by the bank, aggregate Tier 1 capital must be at least $6 \%$, and all capital held must ultimately equal $8 \%$ of liabilities. Andrew L. McElroy, An Examination of Basel III and the New U.S. Banking Regulations, 14 WAKE FOREST J. OF BUS. \& INTELLECTUAL PROPERTY L. 1, 6 (2013).

${ }^{5}$ Id. See also Patrick Jenkins, Q\&A: What Is Bank Capital?, FInANCIAL TIMES, Sept. 13, 2010, www.ft.com/cms/s/.../f98164ba-bf65-11df-965a-00144feab49a.html ("The average bank today probably has a core tier one ratio of about 7 or 8 per cent, compared with a regulatory minimum of 2 per cent, and a tier one ratio of 9 or 10 per cent, compared with a 4 per cent minimum.").
} 
2 requirements. ${ }^{6}$ One of the most important implications of the newest round of banking regulations is that it limits tier 1 capital to include common shares, retained earnings, and other reserves, while Tier 2 capital, and eliminating Basel II's tier 3 capital categorization. ${ }^{7}$ Rethinking not just how much capital should be held by financial institutions, but also what kind of capital needs to be retained is essential to increasing financial stability and one of the "fundamental assumptions of Basel III is that the common equity component of tier 1 capital provides the greatest 'loss absorption' capacity" ${ }^{\text {. As }}$ a result, common equity must make up at least $50 \%$ of the bank's total capital and at least $75 \%$ of the bank's Tier 1 capital. ${ }^{9}$

B. New Regulations Bolster Liquidity

\section{BASEL III'S IMPACT ON CORPORATE GOVERNANCE EFFORTS}

\section{A. What is Corporate Governance?}

Corporate governance is broadly categorized as "the process by which business decisions are made and the process by which persons who will make those decisions are chosen" ${ }^{\prime 10}$. However, it can be more narrowly seen as the framework to address the agency costs that corporations incur as a result of the diverging interests of shareholders and officers/directors. ${ }^{11}$ There are a variety of different mechanisms that corporations, shareholders, and the legal system employ that constitute the corporate governance system, which is the legal and factual atmosphere in which publically held corporations operate. ${ }^{12}$ While the traditional view is that corporate governance systems and structures are supposed to reduce agency costs by giving shareholders some iota of control over corporate

\footnotetext{
${ }^{6}$ Increases in just the amount of capital held will not accomplish much to reform or stabilize the financial system. See Martin Wolf, Basel: The Mouse That Did Not Roar, FinANCIAL TIMES (Sept. 14, 2010), http://www.ft.com/cms/s/0/966b5e88-c034-11df-b77d-00144feab49a.html (noting that too much weight should not be placed in numeric increases in capital requirements, as increase in the amount of non-quality capital does not do much to strengthen financial stability). As a result, Basel III has also increased the requirements for the quality of capital that can be counted towards a financial institution's capital reserve requirement.

${ }^{7}$ Baltali and Tanega, supra note 1 , at 18.

${ }^{8}$ Id. at $18-19$.

${ }^{9}$ Sarah Padgett, Note, The Negative Impact of Basel III on Small Business Financing, 8 OHIO ST. ENTREPRENEURIAL Bus. L.J. 183, 185 (2013).

${ }^{10}$ David C. McBride, For Whom Does this Bell Toll?, 27 DEL. LAW. 28, 29-30 (2009).

${ }^{11}$ Cory Howard, Amgen and Proving Materiality in Class Action Securities Litigation: How the Seventh and Ninth Circuit's Approach to Materiality Offers the United States Supreme Court the Chance to Reinforce Legal Mechanisms of Corporate Governance, 13 WAKE FOREST J. BUS. \& INTELL. PROP. LAW. 257, 268 (2013).

12 Amir N. Licht, The Mother of All Path Dependencies Toward a Cross-Cultural Theory of Corporate Governance Systems, 26 DEL. J. CORP. L. 147, 149 n. 1 (2001)(noting that the 'corporate governance system' is made up of corporate governance rules (company law), corporate governance structures (shareholding patterns), and securities regulation rules).
} 
decision makers ${ }^{13}$, recently, academics and policymakers have begun to question whether stakeholders should be excluded from the corporate governance discussion. ${ }^{14}$ As a result, when discussing Basel III's impact on corporate governance it is imperative that the effects on nonshareholder stakeholders are brought to the forefront, as the reforms that the newest round of banking regulations attempt to implement are to cure deficiencies that disproportionately hurt creditors, employees, and communities tied to corporations that participated in or were severely affected by the 2007 financial crisis.

\section{B. Can Increased Compliance Costs Create a Market for Corporate Governance?}

\section{Basel III's Effect on Compliance Costs}

One of the key concerns that banking industry professionals have expressed about the new banking regulations is that financial institutions will incur increased compliance costs from meeting new capital requirements to increased borrowing costs. ${ }^{15}$ Although proponents of the new capital and banking regulations believe that the system-wide stability that the new regulations will create are worth any increased compliance costs at the firm level, policymakers have been warned that the costs could be significant. ${ }^{16}$ However, not all financial institutions are concerned with the costs of implementing Basel III's capital regulations, as JPMorgan Chase has called the costs 'manageable' and noted that as recently as the second quarter of this year, their available capital levels already met the new proposed regulations. ${ }^{17}$

\footnotetext{
${ }^{13}$ Carol Goforth, Proxy Reforms as a Means of Increasing Shareholder Participation in Corporate Governance: Too Little, but not Too Late, 43 AM. U. L. REV. 379, 409 (1994)(noting that as shareholder participation in corporate governance forums has increased, reforms have been focused on increasing their power and say in the corporate affairs).

${ }^{14}$ For an extended discussion on the role of non-shareholder stakeholders see generally, John C. Coffee Jr., Unstable Coalitions: Corporate Governance as a Multiplayer Game, 78 GEO. L.J. 1495 (1990); Jonathan R. Macey, Fiduciary Duties as Residual Claims: Obligations to Nonshareholder Constituencies from a Theory of the Firm Perspective, 84 CoRnelL L. ReV. 1266 (1999); Cory Howard, Corporate Governance as an Economic Theory: Can Non-Economic Principles of Antitrust Law be Imported to Reduce Shareholder Primacy and Promote Stakeholder Objectives?, 5 BocCONI LEG. PAPERS _ (Winter 2014).
}

${ }^{15}$ See Michael Shari, Missing Pieces, GLOBAL FinanCE (Sept. 2011), http://www.gfmag.com/archives/141september-2011/11358-preparing-for-basel-iii.htm|\#axzz2iPMV3awE (quoting corporate executives who believe "the expectation is that this [Basel III] is going to increase overall costs for corporate and companies...to the extent that banks are being asked for a lot more capital, they only have two choices at the end of the day-either accept lower returns or find ways to increase their pricing". Although the ModigilianiMiller Theorem and Professor Anat Admati of Stanford predict that increased costs in equity financing should conversely lower capital and debt based financing, a number of authors have challenged this assertion. See generally Cory Howard and Neil Jonas, "Under Pressure": Basel III's Capital Adequacy Requirements Squeeze Broker-Dealer Returns on Equity, Increase Need for Imposition of Uniform Fiduciary Duties, 7 JOHN MARSHALL L.J. _ (2013)(challenging the assertion that increased capital requirements will lead to reduced costs in other forms of financing and thus not have an effect on the value of the firm).

${ }^{16}$ Anghuman Gooptu, Will Basel III Help or Hurt?, CHICAGO PoL’y ReV. (Apr. 24, 2012), http://chicagopolicyreview.org/2012/04/24/will-basel-iii-help-or-hurt/.

${ }^{17}$ Phillip van Doorn, JPMorgan Calls Basel III Leverage Compliance 'Manageable', THE STREET (July 12, 2013), http://www.thestreet.com/story/11976639/1/jpmorgan-calls-basel-iii-leverage-compliance-manageable.html. 
But what exactly are these 'costs' that seem to trouble financial institutions, policymakers, and regulators? Typically, there are two types of costs associated with the imposition of a new regulatory framework, direct costs, such as fees incurred for filing the requisite paperwork, and indirect costs, which can include management costs and the costs that firms internalize to meet new regulations, such as the cost of hiring new personal or training legal and compliance departments. ${ }^{18}$ Recognizing the different costs associated with the implementation of new standards, whether they be pure corporate governance structures or financial regulations, is important because the level of firm and system compliance is tied to costs. If the compliance costs are significant firms can and have abandoned the market or opted not to comply with new regulations, especially if price to pay for noncompliance is not significant enough to scare financial markets into implementing Basel III's standards. ${ }^{19}$

\section{The Market for Corporate Governance}

Although a number of different parties, from institutional shareholders to individual stakeholders, would like to see corporations widely adopt a corporate governance framework, "the science of corporate governance shows that there is no market pressure for optimal corporate governance there is only market pressure for indulgent pro-management corporate governance law" 20 . However, new Basel III regulations, specifically a core metric that the Fed and other nation's central banks will measure and enforce, called the risk-based capital ratio, could align what are now seen as diverging market forces and create a demand for corporations, specifically financial institutions, to adopt corporate governance measures and abandon pro-management decision making. Prior to adopting Basel III's capital ratio, the U.S leverage ratio proved to be widely ineffective in stopping systemic threats to the financial system, as 297 banks failed in the early years of the most recent economic downturn. ${ }^{21}$ In fact, a Government Accountability Office report found that leverage of the largest financial institutions consistently increased up until the 2007 collapse of the financial industry. ${ }^{22}$ Therefore, even though Basel III's banking standards are not strictly a new corporate governance structure, it can, as a set of banking regulations, have an effect on firms that could force them to adopt pro-shareholder and pro-stakeholder policies, thus furthering the goals of corporate governance.

\footnotetext{
${ }^{18}$ Anita Indira Anand, An Analysis of Enabling vs. Mandatory Corporate Governance Structures Post-SarbanesOxley, 31 DEL. J. CORP. L. 229, 243 (2006)(dividing the costs of implementing new regulatory frameworks, specifically corporate governance frameworks, into direct costs and indirect costs).

${ }^{19}$ Id. at 244-245 (noting that high costs of complying with regulations can turn firms away from the market or lead them to forego implementing even mandatory regulation, especially if the cost of non-compliance is not significant enough to scare firms into adopting new regulatory structures).

${ }^{20}$ Steven A. Ramirez, The Special Interest Race to CEO Primacy and the End of Corporate Governance Law, 32 DEL. J. CORP. L. 345, 382 (2007).

${ }^{21}$ John Holman, A Flawed Solution: The Difficulties of Mandating a Leverage Ratio in the United States, 738

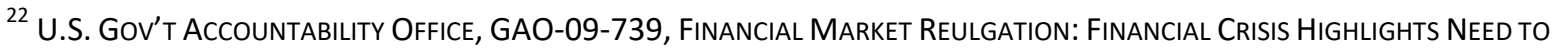
IMPROVE OVERSIGHT OF LEVERAGE AT FINANCIAL INSTITUTIONS AND ACROSS SYSTEM 17, 19, 23-24 [hereinafter GAO LEVERAGE REPORT], http://www.gao.gov/new.items/d09739.pdf.
} 
One of the motivating factors behind the new capital requirements of Basel III was the intent to discourage risky behavior and strengthen current regulatory oversight of financial institutions. ${ }^{23}$ In addition to increasing both the kind and quantity of capital that a bank must hold, Basel III also attempts to reformulate the calculation of risk-weighted assets to discourage banks from using offbalance sheet vehicles to obfuscate the true size of the bank's exposure to risk. ${ }^{24}$ It is the heavy use of these off-balance sheet vehicles that have proved problematic for regulators and have led to the collapse or financial distress of both financial, and non-financial, institutions. In the current market for corporate governance regimes there is simply little incentive for executives to minimize the type of risk taking through off-balance sheet leveraging, as it proves only problematic in times of liquidity and economic distress. To the contrary, current executive compensation practices actually encourage this type of short-term risk behavior by executives. ${ }^{25}$

So what does this mean for corporate governance? Basel III, although it may come with compliance costs, which may end up being significant, has the power to actually skew the market for corporate governance by making it more costly for managers to pursue short-term risk. Although scholars and policy-makers are concerned with the ability of financial institutions to skirt the new regulations ${ }^{26}$, managers would incur the costs of violating federal regulations and international standards to pursue short-term risk. The additional discouragement to holding risky assets that Basel III implements not only promotes shareholders' desire to see managers act in the best long term interests of the company ${ }^{27}$, but also achieves stakeholder objectives, principally by ensuring firm-wide and systemic stability.

\section{Financial System Stability Could Prevent Another 2007 Collapse}

Although Basel III will likely be able to act as a key mechanism in corporate governance by forcing managers away from pro-management decision making that benefits shareholders by ensuring firm stability, it also has the potential to radically help non-shareholder stakeholders. The most recent

${ }^{23}$ Tom Braithwaite, Banks Await Orders as Fed Acts on Basel III, FINANCIAL TIMES (Jul. 2, 2013),
http://www.ft.com/intl/cms/s/0/94abb696-e337-11e2-9bb2-00144feabdc0.html\#axzz2iPRbNz2T.

${ }^{24}$ Wulf A. Kaal, Hedge Fund Regulation Via Basel III, 44 VAND. J. TRANSNAT'L L. 389, 444 (2011)(noting that "central to the rules is an attempt to prevent banks from using off-balance sheet vehicles and risk-weighing methods to hide the true size of their balance sheets").

${ }^{25}$ Cf. Simone M. Sepe, Making Sense of Executive Compensation, 36 DEL. J. CoRP. L. 189, 196-197 (2011)(noting that the standard view among academics after the financial crisis is that equity-based executive compensation packages incentivize managers to take short-term risks); Christine Hurt, Regulating Compensation, 6 OHIO ST. ENTREPRENEURIAL BUS. L.J. 21, 54 (2010-2011)(noting that prior to TARP imposed restrictions on executive compensation, financial firm's compensation practices before the 2007 collapse encouraged intra-firm risk, which, when duplicated throughout interconnected firms, increased systemic risk. However, the author notes that even if risk was perpetrated at the firm level, there is no evidence that it contributed to the collapse of the U.S. economy).

${ }^{26}$ Bank's evasion of financial regulation has always been a problem for regulators, as bank risk models and political pressures may be too much for regulators to be able to carry out effective oversight. See Holman, supra note 16, at 747 (listing a number of factors, including complex risk modeling, greater bank resources to skirt regulations by developing new models that regulators do not understand, and political pressure, as factors that inhibit enforcement of federal regulation). 
financial crisis, which was precipitated by the near-collapse of the financial system, devastated not just shareholders, but specifically and critically hurt corporate stakeholders. Employees, for example, have suffered from decreased employment stability, stagnant wages, and delayed retirement because instability in the financial markets had catastrophic effects that touched almost every industry. ${ }^{28}$ While Basel III is concerned primarily with ensuring that banks and other financial institutions have the requisite capital to withstand another financial crisis, ${ }^{29}$ it is exactly this predicament that deepened the most recent financial crisis.

C. Transparency and Increased Disclosure Requirements

\section{General Disclosure Requirements Strengthen Transparency Efforts}

One of the stated objectives of the Basel III standards is not just to increase capital quality and minimum amounts, but to improve transparency of the capital base as well. ${ }^{30}$ For example, U.S. regulators have required financial holding companies to submit detailed reports that outline the institution's plan for complying with both the Dodd-Frank Act and Basel III. ${ }^{31}$ Transparency is not just a useful byproduct of post-financial crisis standard setting; rather, there is a concerted efforts amongst financial regulators to address the perceived inadequacy of transparency mechanisms. ${ }^{32}$ However, to date, academics, courts, and private organizations have been primarily concerned with efforts to increase non-firm specific transparency. The focus on financial regulation appears to be on whether the Basel Committee publishes their standards online, whether governments embrace transparency and open rulemaking processes, or whether administrative agencies open up their rulemaking for public comment. ${ }^{33}$

\footnotetext{
${ }^{28}$ Binyamin Appelbaum, Recession's Lasting Effects, EXonOMIX: NeW YORK TIMES (Mar. 23, 2012), http://economix.blogs.nytimes.com/2012/03/23/recessions-lasting-effects/ (noting that chronic employment, stagnant wages, and future earning potential of workers have all been damaged by the 2007 recession).

${ }^{29}$ Emilios Avgouleas, Rationales and Designs to Implement An Institutional Big Bang in the Governance of Global Finance, 36 SEATTLE U. L. REV. 321, 373 (2013)(noting that the promulgation of Basel III was intended to address chronic undercapitalization of financial institutions).

${ }^{30}$ See Basel Committee on Banking Supervision, Bank for International Settlements, StRengthening the Resillance OF THE BANKIng SeCtor: CONSUltative Document 13 (2009), http://www.bis.org/publ/bcbs164.pdf (noting that the highest priority issues for Basel III was the "need to strengthen the quality, consistency, and transparency of the regulatory capital base".).

${ }^{31}$ Andrew L. McElroy, An Examination of Basel III and the New U.S. Banking Regulations, 14 WAKE FOREST J. OF Bus. \& INTEllectual Property L. 1, 4 (2013)(citing BD. OF GOVERNORS OF THE FED. RESERVE SYS., COMPREHENSIVE CAPITAL ANALYSIS AND REVIEW: OBJECTIVES AND OVERVIEW 1 (2011), available at http://www.federalreserve.gov/newsevents/press/bcreg/bcreg20110318a1.pdf.).

${ }^{32}$ Caroline Bradley, Transparency is the New Opacity: Constructing Financial Regulation After the Crisis, 1 AM. U. BUS. L. REV. 7,7 (2011).

${ }^{33}$ Id. at 12-14 (noting a number of transparency-related reforms that have been implemented in post-financial crisis rulemaking. Notably absent from the discussion of major success are firm-specific efforts to increase corporate transparency).
} 
This type of general, non-firm specific efforts at transparency are essential to furthering corporate governance objectives at both the shareholder and stakeholder level as it encourages participation in disenfranchised segments of corporate constituencies.

\section{Basel III's Firm-Specific Disclosure Requirements Achieve Corporate Governance Objectives by making Transparent Previously Hidden Information}

Although increased transparency in the dissemination of regulations does further corporate governance objectives, what is particularly notable about Basel III are the firm-specific disclosure requirements. Just as the disclosure requirements of the Dodd-Frank Act were intended to promote accountability, ${ }^{34}$ the disclosure requirement of Basel III are intended to all shareholders, or at least potential shareholders, to get an accurate picture of a financial institution's financial statements, insuring that banks maintain proscribed capital reserves and acceptable leverage ratios. ${ }^{35}$ But it is not just the mandatory disclosure that makes Basel III a stronger corporate governance tool than DoddFrank, but the specific enunciation of what must be disclosed.

For example, paragraph 56 of the Disclosure Requirements force a bank to report a "breakdown of the following exposures under the scope of consolidation of the leverage ratio framework: on-balance sheet exposures, derivative exposures, securities financing transaction exposures, and other off-balance sheet exposures" ${ }^{\prime 3}$. The inclusion of off-balance sheet exposures is important because off-balance sheet exposures have posed systemic threats to the United States, and worldwide economy, since the collapse of Enron ${ }^{37}$ and several other important corporate governance and financial regulation legislation have been unsuccessful in forcing their compete disclosure. Section 401(a) of the Sarbanes-Oxley Act ("SOX") attempted to mitigate the risk of hidden liabilities by forcing companies to disclose material off-balance sheet transactions. ${ }^{38}$ By assigning a credit conversion factor to each particular type of off-balance sheet exposure ${ }^{39}$ and specifically enunciating the types of off-balance sheet exposures that banks must disclose, regulators under Basel III are able

\footnotetext{
${ }^{34}$ See The Wall Street Reform and Consumer Protection Act of 2010, Pub. L. No. 111-203, 124 Stat. 1376 (2010) [hereinafter Dodd-Frank]; Mirela V. Hristova, V. Dodd-Frank's Corporate Governance Reform, 30 REV. BANKING \& FIN. L. 516, 519-520 (2011).

${ }^{35}$ See Basel Committee on Banking Supervision, ReVised BASEl III LeVerage Ratio Framework ANd DisClosure REQUIREMENTS 8 १44 [HEREINAFTER, “DISClosuRe REQUIREMENTS\} (June 2013), available at http://www.bis.org/publ/bcbs251.pdf.

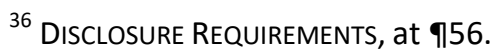

${ }^{37}$ See Jim Brunsden, Bank's Off-Balance-Sheet Risks Come Under Basel Scrutiny, BLOOMBERG (Sept. 30, 2013), http://www.bloomberg.com/news/2013-09-29/banks-face-basel-debt-limit-capturing-off-balance-sheetrisks.html (noting that complex banking procedures, specifically the shifting of risky assets and liabilities off of a bank's disclosed balance sheet was one of the primary causes of the 2007 collapse).

${ }^{38}$ Sarbanes-Oxley Act of 202, Pub. L. No. 107-204, § 401, 116 Stat. 745, 786 (codified in scattered sections of 15 U.S.C.)(requiring the disclosure of "off-balance sheet transactions that may have a material current or future effect on the financial condition, changes in financial condition, results of operations, liquidity, capital expenditures, capital resources, or significant components of revenues or expenses").
} 
to better quantify the true leverage of a bank, ${ }^{40}$ and for what appears to be the first time, take proper inventory of a bank's off-balance sheet exposure. ${ }^{41}$ In addition to the disclosure of off-balance sheet holdings, Basel III requires banks to publish "contractual mismatches between on- and off- balance sheet flows at various time frames...[and] explain how such mismatches will be bridged." 42

These new disclosure requirements of Basel III do not appear to be the same smoke-andmirror reforms that Sarbanes-Oxley imposed in the post-Enron era. While SOX § 401(a) and Rule 46-R both came under heavy scrutiny in the immediate aftermath of the 2007 credit crunch for their failure to appropriately control off-balance sheet exposure, specifically the proliferation of dangerous special-entity vehicles ${ }^{43}$, Basel III has greater disclosure and regulatory power. One of the main criticisms hurled against SOX's § 401(a) was that it permitted liabilities to be left off quarterly and annual disclosures when the risk primarily laid with others, which left investors without knowledge of unreported risk until the risk went bad. ${ }^{44}$ However, Basel III's itemized disclosure of derivatives and other risk-bearing liabilities, which is not dependent on a easily manipulated decision of where the risk may lay, coupled with contractual mismatch explanations, promises to ensure that investors and regulators are able to identify off-balance sheet risk before it becomes a problem. This does not just increase firm-specific transparency in a meaningful way, it also enfranchises both financial regulators and shareholders, two parties who have often met stiff resistance in their attempts to participate in the corporate governance efforts aimed at financial institutions. ${ }^{45}$

\footnotetext{
${ }^{40}$ Shadow Financial Regulatory Committee, Statement of the SHAdow Financial Regulatory Committee on IMPRoving CAPITAL AdequaCy Disclosure 2 (Feb. 11, 2013), http://fic.wharton.upenn.edu/fic/Policy\%20page/Statement\%20No.\%20335\%202.13.pdf (recommending adoption of the Basel Committee's proposed leverage ratio as it better accounts for off-balance sheet liabilities in measuring total exposure).

${ }^{41}$ Financial institutions and companies, such as Enron, had been able to manipulate loopholes in disclosure rules and securities regulation by not-reporting off-balance sheet exposures that totaled substantial sum of recourse debt; debt which was not factored by credit agencies which eventually led to the precipitious collapse of the firm. See Frank Partnoy, A Revisionist View of Enron and the Sudden Death of "May", 48 VILL. L. REV. 1245, 1250-1251 (2003)(explaining how Enron manipulated non-disclosed off-balance sheet exposures to artificially buoy its credit rating and access to cheap forms of liquidity).

${ }^{42}$ Adrian Blundell-Wignall and Paul Atkinson, Thinking Beyond Basel III: Necessary Solutions for Capital and Liquidity, 2010 OCED JOURNAL: FIN. MARKET TRENDS 9, 28 (2010).

${ }^{43}$ See Floyd Norris, Off-the-Balance-Sheet Mysteries, N.Y. TIMES (Dec. 8, 2008), http://www.nytimes.com/2008/02/28/business/worldbusiness/28iht-norris29.1.10520588.html? r=0 (raising questions as to the efficacy of SOX's off-balance sheet exposure reporting requirements).

${ }^{44}$ Id.

${ }^{45}$ See Oskari Juurikkala, The Behavioral paradox: Why Investor Irrationality Calls for Lighter and Simpler Financial Regulation, 18 FORDHAM J. CORP. \& FIN. L. 33, 78 (2012)(noting that financial regulators often fail in their responsibilities because of lack of information, deficient skills, as well as incentive problems); Carrie Stradle Lavargna, Government-Sponsored Enterprises are "Too Big to Fail": balancing Public and Private Enterprises, 44 HASTINGS L.J. 991, 1019 (1993)(noting that governmental interests are placed above shareholders rights and give them no power to control or seek redress against financial instability of financial institutions). This presents an interesting conundrum for financial regulation, as both regulators and shareholders have been deemed incapable of controlling financial institutions.
} 
Greater transparency at the firm level, especially disclosure of accurate financial statements is one of the most significant corporate governance (and regulatory) advancements in the post-Great Recession environment and has long been an objective of the Obama Administration. In fact, a White Paper published by the Obama Administration, "A New Foundation: Rebuilding Financial Supervision and Regulation", was, if not the first, then the most radical, call to imbue regulators with the power to eliminate risky behavior in the financial sector before it could become a systemic threat. $^{46}$ One of the primary concerns that the report sought to remedy was the existence of inadequate disclosure regimes, which skewed risk-based decisions taken by lenders, securitizes, and investors. ${ }^{47}$ Therefore, the white paper, proposed, among a number of other reforms, increased public disclosures by Tier 1 Financial Holding Companies (Tier 1 FHC) in order to allow investors, regulators, and market participants to properly evaluate the risk profile, risk management ability, and capital adequacy of systemically important financial companies. The increased disclosure standard of Basel III will accomplish this goal, albeit six years after the public release of the white paper, by forcing banks and financial institutions to make disclosures of capital holdings, off-balance-sheet assets (which have in the past proved to be a major source of hidden risk), and otherwise unregulated derivatives.

This benefits investors and market participants by permitting them to get an accurate view of a publically traded financial institution's risk exposure, but also reduces the risk to the financial system. Publically traded financial institutions such as Citigroup, Bank of America, J.P. Morgan Chase and others will be forced to make accurate disclosures, lest their incorrect disclosures be used as evidence in a Rule $\S 10 \mathrm{~b}-5^{48}$ class-action securities lawsuit against the bank. Not only does Basel III's disclosure requirement benefit shareholders and potential market participants through the guarantee of correct, and absolute, disclosure, but it also protects consumers and corporate stakeholders by buttressing the stability of the financial system. This occurs not only through increased confidence in transparent financial institutions, but also by enhancing market discipline. ${ }^{49}$

\footnotetext{
${ }^{46}$ Robert G. Kaiser, ACT OF CONGRESS: How AMERICA'S ESSENTIAL INSTITUTION WORKS, AND HOW IT DOESN'T 92 (2013)(noting that the white paper commissioned after the beginning of the financial collapse of 2007 introduced the idea of terminating risky financial behavior before it could threaten the system, considered a novel reform in American capitalism).

47 Dep't of the Treasury, A New Foundation: Rebuilding Financial Supervision and Regulation 44 (2009).

${ }^{48}$ S.E.C. Rule $10 b-5$ is a regulatory prohibition against the type of activity prohibited by $\S 10(b)$ of the Securities Exchange Act of 1934. See 15 U.S.C. §78j(b). In a typical §10(b) action the plaintiff must prove (1) material misrepresentation or omission by the defendant (an issuer of securities), (2) scienter, (3) a connection between the misrepresentation or omission and the purchase or sale of security, (4) reliance, (5) economic loss, and (6) loss causation. See Dura Pharmaceuticals, Inc. v. Broudo, 544 U.S. 336, 341-342, 125 S.Ct. 1627 (2005).

${ }^{49}$ Press Release, Financial Stability Board, FSB Welcomes Implementation Progress Report by the Enhanced Disclosure Task Force (Aug. 21, 2013), available at http://www. financialstabilityboard.org/press/pr 130821.pdf.
} 


\section{CONCLUSION}

Although the new standards promulgated by the Basel Committee on Banking Supervision are primarily seen as a way to achieve financial system-wide stability, they also have the ability to significantly further corporate governance objectives, especially those of non-shareholder stakeholders. These corporate governance objectives will be advanced in two primary methods: (1) increasing the capital adequacy requirements of financial institutions and (2) by increasing transparency. Both of these components of financial regulation are currently undergoing strenuous reform, as financial holding companies will be forced to recalculate their capital retention levels and enhance their public disclosures, including a number of previously hidden, but risky liabilities, to investors and stakeholders. By forcing banks to not only hold more capital, and improve the capital of the quality held, as well as force banks to disclose, and thus discourage the holding of liabilities that greatly enhance risk exposure, Basel III will use firm-specific reforms to enhance the stability of the financial system as a whole. Therefore, giving shareholders a clearer image of the risk management capabilities of potential investors is not the only corporate governance reform that Basel III brings, but it also reduces agency costs by discouraging management's high-profit, high-risk, short-term profit maximizing decision making, but also protects consumers, borrowers, and other unseen victims from another 2007 financial catastrophe. 
